УДК 343.21

\title{
ШІ.Ф. Багаутдинов
}

\section{ОСНОВНЫЕ ПРИНЦИПЫ И ОБЩИЕ УСЛОВИЯ ПРОИЗВОДСТВА ПО УГОЛОВНЫМ ДЕЛАМ О ПРЕСТУПЛЕНИЯХ, СОВЕРШЕННЫХ НЕСОВЕРШЕННОЛЕТНИМИ И В ОТНОШЕНИИ НЕСОВЕРШЕННОЛЕТНИХ}

С учетом поправки в Конституцию Российской Федерации 2020 г. о приоритете детства (част 4 ст. 67.1 ) в статье сформулированы предложения о введении в УПК РФ положений об основных принципах и общих условиях производства по уголовным делам о преступлениях, совершенных несовершеннолетними и против несовершеннолетних. Для развития данной новеллы закона предлагаем расширить возможности обеспечения квалифицированной юридической помощью несовершеннолетних потерпевших - предоставить такую возможность для всех несовершеннолетних, не достигших возраста 18 лет, которые стали потерпевшими в результате тяжких и особо тяжких преступлений, а также всем несовершеннолетним, не достигшим возраста 16 лет, которые стали потерпевшими в результате совершения преступлений любой тяжести; о наличии такого права несовершеннолетнему и его законному представителю должен разъяснить следователь, руководитель следственного органа, прокурор, суд. Только такой подход поможет обеспечить действительный приоритет прав несовершеннолетних потерпевших в уголовном судопроизводстве.

Ключевые слова: производство по уголовным делам о преступлениях несовершеннолетних и против несовершеннолетних; принципы уголовного законодательства; принципы уголовного судопроизводства; общие условия предварительного расследования.

DOI: $10.35634 / 2412-9593-2022-32-1-119-124$

Производство по уголовным делам о преступлениях несовершеннолетних, предусмотренное гл. 50 УПК РФ, имеет в своей основе Минимальные стандартные правила $\mathrm{OOH,} \mathrm{касающиеся} \mathrm{отправле-}$ ния правосудия в отношении несовершеннолетних (Пекинские правила), которые рекомендуют создание специализированных судов по делам семьи и несовершеннолетних, требуют наличия соответствующей квалификации у лиц, осуществляющих производство по делам несовершеннолетних. Именно правосудие по делам о преступлениях несовершеннолетних составляет основу понятия «ювенальная юстиция».

Выделяют следующие основные принципы ювенальной юстиции: преимущественно охранительная ориентация; социальная насыщенность (привлечение к участию в процессе специалистов - не юристов и использование помощи социально-психологических служб); максимальная индивидуализация судопроизводства ${ }^{1}$.

При этом, хотя и специализация прямо не названа в качестве принципа ювенальной юстиции, именно она является определяющей, и способствует успешной реализации индивидуального подхода к каждому несовершеннолетнему, и в целом максимальной индивидуализации предварительного следствия и всего судебного процесса.

Предварительное расследование и правосудие по делам несовершеннолетних в Российской Федерации осуществляются, исходя из общих принципов уголовного судопроизводства, не имеют самостоятельного специального правового регулирования, а лишь содержат отдельные особенности и правила для таких дел.

В юридической науке обоснованно отмечается особый порядок производства по уголовным делам о преступлениях, совершенных несовершеннолетними, позволяет, наряду с общими задачами судопроизводства, решать и специфические ювенальные задачи ${ }^{2}$.

В целом правосудие в отношении несовершеннолетних должно быть основано не на снисхождении к правонарушителям, а на понимании причин преступного поведения и поиске эффективных способов воздействия на виновных с учетом их возрастных особенностей: цель правосудия в отно-

\footnotetext{
${ }^{1}$ Подробнее об этом см.: Мельникова Э.Б. Ювенальная юстиция. Проблемы уголовного права, уголовного процесса и криминологии. М., Дело, 2001.

${ }^{2}$ Сычев А.А. Дифференциация уголовно-процессуальной формы производства по делам несовершеннолетних: автореф. дис. ... канд. юрид. наук. Н. Новгород, 2009. С. 16.
} 
шении несовершеннолетних - попытаться избежать дальнейшей криминализации личности и способствовать ее социальной реабилитации, а не отчуждению от общества ${ }^{3}$.

Как подчеркнул Конституционный Суд Российской Федерации, детство - это период физической, умственной и психологической незрелости и одновременно важнейший этап развития личности, на котором закладываются основы моральных и нравственных качеств, формируются мировоззрение и взгляды, определяющие жизненные принципы и перспективы. Обеспечение благополучного и защищенного детства является конституционно признаваемой обязанностью государства. Для этого требуется разработка и проведение эффективной правовой политики в этой области, направленной на недопущение дискриминации несовершеннолетних, упрочение гарантий их прав и законных интересов, а также восстановление этих прав в случаях их нарушения, формирование правовых основ гарантий прав ребенка ${ }^{4}$.

В соответствии с поправкой в Конституцию РФ от 14 марта 2020 г. (ч. 4 ст. 67.1), государство, обеспечивая приоритет семейного воспитания, берет на себя обязанности родителей в отношении детей, оставшихся без попечения. Для реализации данной поправки целесообразно обсудить важный вопрос о разработке и формулировании основных принципов и общих условий производства по уголовным делам с участием несовершеннолетних.

В Главе 2 Уголовно-процессуального кодекса Российской Федерации закреплены принципы уголовного судопроизводства, то есть основные положения, определяющие его сущность и содержание, относящиеся ко всем стадиям уголовного судопроизводства, ко всем участникам судопроизводства, к любым категориям и видам преступлений.

Кроме этого, в Разделе VIII УПК РФ (Предварительное расследование) содержится Глава 21 Общие условия предварительного расследования, которая имеет важное значение и распространяется также на всех участников судопроизводства, на все категории и виды преступлений.

Уголовный кодекс Российской Федерации также закрепляет собственные задачи и принципы. В то же время в Уголовном кодексе РФ и в Уголовно-процессуальном кодексе РФ не сформулированы самостоятельные, специальные принципы применительно к производству по уголовным делам с участием несовершеннолетних. С учетом закрепления в 2020 г. интересов и прав детей в качестве важнейшего конституционного приоритета государственной политики требуется, на наш взгляд, определение основных принципов уголовного судопроизводства - применительно к несовершеннолетним. Такой подход поможет обеспечить действительный приоритет прав и интересов несовершеннолетних.

Предлагаем, в частности, ввести в Главу 50 УПК РФ положения об основных принципах и общих условиях производства по уголовным делам о преступлениях, совершенных несовершеннолетними и в отношении несовершеннолетних.

При формулировании основных принципов производства по делам несовершеннолетних, безусловно, следует руководствоваться международно-правовыми подходами и стандартами, используя зарубежные ювенальные технологии, с учетом собственной российской практики и исторического отечественного опыта. Одним из основных принципов производства по уголовным делам о преступлениях несовершеннолетних и в отношении несовершеннолетних, на наш взгляд, должно стать требование о безусловном учете интересов семьи.

Законодательная концепция судопроизводства по делам несовершеннолетних должна строиться с учетом функциональной характеристики института семьи в целом и учитывать интересы семьи в уголовном процессе 5 . Однако данному вопросу как законодательство, так и правоприменительная практика должного внимания не уделяют.

В соответствии с ч. 3 ст. 60 Уголовного кодекса РФ, при назначении наказания учитываются характер и степень общественной опасности преступления и личность виновного, в том числе обстоятельства, смягчающие и отягчающие наказание, а также влияние назначенного наказания на ис-

\footnotetext{
3 Ламинцева С.А. Процессуальные гарантии реализации прав несовершеннолетних в уголовном судопроизводстве // Судья. 2017. № 4. С. 44.

${ }^{4}$ Постановление Конституционного Суда Российской Федерации от 18 июля 2013 г. № 19-П «По делу о проверке конституционности пункта 13 части первой статьи 83, абзаца третьего части второй статьи 331 и статьи 351.1 Трудового кодекса Российской Федерации в связи с жалобами граждан В.К. Барабаш, А.Н. Бекасова и других и запросом Мурманской областной Думы».

5 Дежнев А.С. Охрана интересов семьи и несовершеннолетних в уголовном процессе России: автореф. дис. ... докт. юрид. наук. Омск, 2013. С. 10-11.
} 
Основные принципы и общие условия производства по уголовным делам...

правление осужденного и на условия жизни его семьи. Это, пожалуй, одно из редких упоминаний в Уголовном кодексе РФ об интересах семьи.

На практике вопрос о влиянии назначенного наказания на условия жизни семьи осужденного, как правило, рассматривается применительно к взрослому лицу - то есть ставится вопрос о том, как будет семья жить без отца, без матери. По смыслу закона, данное положение не применимо к несовершеннолетнему осужденному. Как оценить влияние назначенного несовершеннолетнему наказания на условия жизни его родителей? Например, осудили несовершеннолетнего к лишению свободы? Да, родителям наверняка морально будет тяжело, они будут переживать и так далее, но не более того.

Легче обосновать этот вывод в отношении взрослого лица, у которого на свободе остаются несовершеннолетние дети. И сложно его обосновать при осуждении несовершеннолетнего, когда на свободе остаются его трудоспособные здоровые родители. Как нам кажется, при назначении наказания несовершеннолетнему обсуждаемая формулировка не применима в целом. Здесь нужны другие акценты. Возможно, что следует вести речь о влиянии назначенного несовершеннолетнему наказания на другие права несовершеннолетнего - например, на возможность продолжения учебы, возможность получения квалифицированной медицинской помощи и др. На наш взгляд, при назначении наказания несовершеннолетнему необходимо учитывать комплекс его прав, которых он лишается, в случае осуждения к лишению свободы.

В этой связи мы полностью солидарны с мнением о том, что неблагополучное положение в семье, плохие условия жизни и воспитания несовершеннолетних, которые способствовали совершению ими преступлений, должны учитываться в качестве смягчающего обстоятельства при решении вопроса об ответственности несовершеннолетних за совершенные ими деяния ${ }^{6}$.

Одним из принципов уголовного судопроизводства в целом является его гласность. Данный принцип содержит серьезные ограничения в производстве по уголовным делам о преступлениях несовершеннолетних и в отношении несовершеннолетних. Поэтому следует вести речь о принципе гласности и конфиденциальности - одновременно, в совокупности.

Еще И.Я. Фойницкий обращал внимание на то, что гласность судопроизводства создает в глазах несовершеннолетних ложный ореол преступления, преувеличивает значение преступной деятельности и увлекает несовершеннолетних в привычную преступность. Торжественность судебного процесса нередко служит возвеличиванию преступления и возбуждает стремление к ложной славе между преступниками. Гласность судебного разбора превращает зал суда как бы в школу преступлений. Поэтому важным представляется упрощение судебного следствия и сглаживание обрядовой стороны судебного разбирательства, до сведения ее к свободной беседе судьи с обвиняемым ${ }^{7}$.

Все эти оценки, высказанные более века назад, не утратили своей актуальности. Более того, в современных условиях мгновенного распространения информации через средства массовой информации они еще более актуализировались.

Чрезмерная гласность судебных процессов в отношении несовершеннолетних способна причинить огромный моральный вред. В современных условиях важно ограничение публикаций в средствах массовой информации по делам несовершеннолетних.

Постановление Пленума Верховного Суда Российской Федерации от 1 февраля 2011 г. «О судебной практике применения законодательства, регламентирующего особенности уголовной ответственности и наказания несовершеннолетних» напоминает о Пекинских правилах 1985 г., гласящих, что право на конфиденциальность информации о несовершеннолетнем подозреваемом, обвиняемом, подсудимом должно обеспечиваться на всех стадиях процесса, чтобы избежать причинения несовершеннолетнему вреда и ущерба его репутации. Исходя из этих рекомендаций, судам надлежит не допускать рассмотрение уголовных дел в отношении несовершеннолетних и материалов о совершенных ими правонарушениях с участием представителей средств массовой информации, а также использование видео- и фотосъемки несовершеннолетних правонарушителей и потерпевших в залах судебных заседаний и в других помещениях судов, за исключением случаев, когда несовершеннолетний и (или) его законный представитель ходатайствуют об этом.

\footnotetext{
${ }^{6}$ Еникеев Р.З. Проблемы доказывания в деятельности адвоката-защитника по делам о преступлениях несовершеннолетних: автореф. дис. ... канд. юрид. наук. Ижевск, 2004. С. 11.

${ }^{7}$ Фойницкий И.Я. Курс уголовного судопроизводства. Т. ІІ. СПб.: Изд-во «Альфа», 1996. С. 504-507.
} 
Ограничения гласности и обеспечения конфиденциальности требует правило 8 Минимальных стандартных правил $\mathrm{OOH}$, касающихся отправления правосудия в отношении несовершеннолетних (Пекинские правила). В нем подчеркнуто, что право несовершеннолетних на конфиденциальность должно уважаться на всех этапах, чтобы избежать причинения несовершеннолетнему вреда из-за ненужной огласки или из-за возможности нанесения ущерба репутации несовершеннолетнего. Поэтому нельзя публиковать любую информацию, которая может привести к указанию на личность несовершеннолетнего правонарушителя, с учетом того, что несовершеннолетние лица особо болезненно реагируют на нанесение ущерба репутации.

В законодательстве ведущих зарубежных стран (Англия, Франция, США и др.) содержится запрет сообщать кому-либо, в том числе и средствам массовой информации, любые подробности и сведения, которые могут привести к идентификации несовершеннолетнего участника уголовного судопроизводства. Такие же запреты установлены применительно к демонстрации изображения ребенка в газете или телепрограмме. При этом предусмотрена уголовная ответственность за опубликование сведений о несовершеннолетних, вопреки установленным запретам ${ }^{8}$. Однако российское законодательство не предусматривает ни уголовной, ни административной ответственности за незаконное опубликование сведений о несовершеннолетних участниках уголовного судопроизводства, что, безусловно, является серьезным изъяном.

В УПК РФ содержится ряд положений, направленных на ограничение действия принципа гласности в уголовном судопроизводстве по делам о преступлениях несовершеннолетних.

Основная в этом контексте статья - ст. 241 (Гласность) - указывает, что закрытое судебное заседание допускается на основании определения или постановления суда в определенных случаях, в том числе когда рассматриваются уголовные дела о преступлениях, совершенных лицами, не достигшими возраста шестнадцати лет. Здесь конкретно указывается на возраст несовершеннолетнего подсудимого - не достигшие шестнадцати лет.

Кроме этого, закрытое судебное разбирательство допускается по уголовным делам о преступлениях против половой неприкосновенности и половой свободы личности и других преступлениях, когда их рассмотрение может привести к разглашению сведений об интимных сторонах жизни участников уголовного судопроизводства либо сведений, унижающих их честь и достоинство. Здесь речь идет в том числе и о подобных преступлениях, совершенных против несовершеннолетних.

Также закрытое судебное разбирательство допускается, когда этого требуют интересы обеспечения безопасности участников судебного разбирательства, их близких родственников или близких лиц. При этом речь может идти в том числе и об обеспечении безопасности несовершеннолетних участников судебного разбирательства.

Определение или постановление суда о проведении закрытого судебного разбирательства не может быть произвольным. В нем должны быть указаны конкретные, фактические обстоятельства, на основании которых суд принял подобное решение.

Основным, наиболее распространенным основанием для проведения закрытого судебного разбирательства является факт не достижения шестнадцатилетнего возраста подсудимым. В этой связи полагаем, что перечень оснований для закрытого судебного разбирательства применительно к несовершеннолетним целесообразно дополнить, например, таким основанием: когда подсудимый и потерпевший на момент совершения преступления являлись несовершеннолетними. Такие случаи не редкость в правоприменительной практике, и подобные дела требуют тишины, сокрытия от посторонних глаз. Ведь речь идет о тонких материях взаимоотношений между детьми, которые не всегда очевидны и понятны для взрослых.

Следуя международно-правовым стандартам, предлагаем закрепить в производстве по уголовным делам о преступлениях несовершеннолетних и против несовершеннолетних соответствующий принцип - принцип ограничения гласности и обеспечения конфиденциальности.

Необходимо не только ввести такой принцип, закрепить его в уголовно-процессуальном законодательстве, важно наполнить его реальным содержанием, сформировав основные положения закона, которые и будут составлять его элементы, составные части.

\footnotetext{
${ }^{8}$ Суды по делам несовершеннолетних в отдельных капиталистических странах //Законодательство зарубежных стран: обзорная информация. Вып. 6. М., 1987. С.5.
} 
Основные принципы и общие условия производства по уголовным делам...

Кроме этого, в качестве принципа уголовного судопроизводства по делам с участием несовершеннолетних обвиняемых и потерпевших следует признать требование о создании режима наибольшего благоприятствования для несовершеннолетних подозреваемого, обвиняемого, подсудимого, осужденного в ходе предварительного следствия и судебного разбирательства.

Создание режима наибольшего благоприятствования для несовершеннолетних подозреваемого, обвиняемого, к примеру, может выражаться во введении правила о возможности ведения следствия и проведения судебного разбирательства не по месту совершения преступления, а по месту его жительства. То есть речь идет о внесении изменений в общие условия предварительного расследования в целом, в частности, в ст. 152 УПК РФ о месте производства предварительного расследования.

Соответственно, с учетом практики развитых государств, например, законодательства Швейцарии 9 предлагаем ввести в УПК РФ специальное правило о том, что расследование и судебное рассмотрение уголовного дела по обвинению несовершеннолетнего может производиться по месту его жительства, а не по месту совершения преступления. Целесообразно возложить решение этого вопроса на прокурора, чтобы именно он, учитывая все обстоятельства дела и интересы его участников, определил место расследования.

Данный принцип применительно к несовершеннолетнему, незаконно привлеченному к уголовной ответственности и получившему право на реабилитацию, мог бы, например, выражаться в практике взыскания компенсации морального вреда в интересах несовершеннолетнего в повышенном, кратном (например, в двойном размере), чем в отношении взрослого лица в аналогичной ситуации. И это было бы справедливым.

Кроме этого, предлагаем закрепить в уголовном законодательстве принцип учета возраста несовершеннолетнего потерпевшего при назначении уголовного наказания, исходя из того, что чем меньше возраст несовершеннолетней жертвы преступления, тем больше общественная опасность совершенного преступления, и тем строже должно быть уголовное наказание. На основе данного подхода следует сформулировать предложения о законодательном выделении в соответствующих составах преступлений трех основных групп несовершеннолетних потерпевших: в возрасте до 7 лет включительно; в возрасте 8-14 лет; в возрасте старше 14 лет.

Определенная градация возраста несовершеннолетнего в отдельных составах УК РФ, в частности, в составах о так называемых половых преступлениях против несовершеннолетних, уже присутствует. Этот подход развивается в законодательстве и дальше. Соответственно, этот подход должен быть закреплен в виде самостоятельного принципа в Уголовном кодексе РФ - как принцип обязательного учета возраста несовершеннолетнего потерпевшего при назначении виновному лицу наказания.

Также в качестве принципа производства по уголовным делам о преступлениях несовершеннолетних и против несовершеннолетних предлагаем закрепить принцип обеспечения права на защиту и юридической помощью для всех несовершеннолетних участников уголовного судопроизводства за счет государства, другими словами, принцип бесплатного следствия и суда для всех категорий несовершеннолетних (подозреваемых, обвиняемых, подсудимых, потерпевших, свидетелей). Данное предложение исходит из того, что подавляющее большинство несовершеннолетних не имеют собственных средств, собственного имущества, не имеют достаточных социальных льгот. Родители, опекуны несовершеннолетних тоже не всегда в состоянии обеспечить им квалифицированную юридическую помощь. Поэтому эту обязанность должно взять на себя государство. Кроме этого, несовершеннолетние осужденные должны быть освобождены от возмещения любых процессуальных издержек.

Особенно важно обеспечить квалифицированную юридическую помощь за счет государства для несовершеннолетних потерпевших. Определенные действия в этом направлении законодатель предпринимает.

Федеральным законом от 28 декабря 2013 г. № 432-Ф3 «О внесении изменений в отдельные законодательные акты Российской Федерации в целях совершенствования прав потерпевших в уголовном судопроизводстве» ст. 45 УПК РФ была дополнена ч. 2.1 следующего содержания: «По ходатайству законного представителя несовершеннолетнего потерпевшего, не достигшего возраста 16 лет, в отношении которого совершено преступление против половой неприкосновенности несовершеннолетнего, участие адвоката в качестве представителя такого потерпевшего обеспечивается дознавате-

\footnotetext{
9 Трефилов А.А. Основы ювенального уголовного процесса Швейцарии. Ч. II // Библиотека криминалиста. Научный журнал. 2018. № 1 (36). С. 353-362.
} 
лем, следователем или судом. В этом случае расходы на оплату адвоката компенсируются за счет средств федерального бюджета».

Данное положение, безусловно, направлено на защиту прав и законных интересов несовершеннолетних потерпевших по преступлениям против их половой неприкосновенности. В литературе уже задавался вопрос - почему речь идет только о половых преступлениях против несовершеннолетних $?^{10}$ Для развития данной новеллы закона предлагаем расширить возможности обеспечения квалифицированной юридической помощью несовершеннолетних потерпевших:

- предоставить такую возможность для всех несовершеннолетних, не достигших возраста 18 лет, которые стали потерпевшими в результате тяжких и особо тяжких преступлений, а также всем несовершеннолетним, не достигшим возраста 16 лет, которые стали потерпевшими в результате совершения преступлений любой тяжести;

- о наличии такого права несовершеннолетнему и его законному представителю должен разъяснить следователь, руководитель следственного органа, прокурор, суд.

Только такой подход поможет обеспечить действительный приоритет прав несовершеннолетних потерпевших в уголовном судопроизводстве.

В статье высказаны лишь отдельные соображения и предложения по вопросам формулирования специальных принципов и общих условий для производства по уголовным делам о преступлениях несовершеннолетних и против несовершеннолетних. Эти вопросы требуют широкой дискуссии с участием ученых и практических работников.

Поступила в редакцию 03.12.2021

Багаутдинов Шамиль Флерович, руководитель следственного отдела по Советскому району г. Казань Следственное управление Следственного комитета России по Республике Татарстан 420087, Россия, г. Казань, ул. Курчатова, 10

\section{Sh.F. Bagautdinov \\ BASIC PRINCIPLES AND GENERAL CONDITIONS OF PROCEEDINGS IN CRIMINAL CASES ON CRIMES COMMITTED BY MINORS AND AGAINST MINORS}

DOI: $10.35634 / 2412-9593-2022-32-1-119-124$

Taking into account the amendment to the Constitution of the Russian Federation of 2020 on the priority of childhood (part 4 of article 67.1), the article formulates proposals to introduce into the Code of Criminal Procedure of the Russian Federation provisions on the basic principles and general conditions of proceedings in criminal cases of crimes committed by minors and against minors. To develop this novelty of the law, we propose to expand the possibilities of providing qualified legal assistance to minor victims - to provide such an opportunity for all minors under the age of 18 who became victims of serious and especially serious crimes, as well as for all minors under the age of 16, who became victims as a result of committing crimes of any gravity; the presence of such a right to a minor and his legal representative must be explained by the investigator, the head of the investigative body, the prosecutor, the court. Only such an approach will help ensure the real priority of the rights of juvenile victims in criminal proceedings.

Keywords: criminal proceedings on crimes of minors and against minors; principles of criminal law; principles of criminal justice; general conditions of preliminary investigation.

Поступила в редакцию 03.12.2021

Bagautdinov Sh.F., Head of the Investigation Department for the Sovetsky district of Kazan Investigative department of Investigative Committee of Russia for the Republic of Tatarstan Kurchatova st., 10, Kazan, Russia, 420087

\footnotetext{
${ }^{10}$ Быков В. Новый закон о правах потерпевшего в уголовном судопроизводстве // Законность. 2014. № 4. С. 36-40.
} 